\title{
The Role of Cinema and the Effect of Educational Levels of Politicians on Voting Attitude
}

\author{
Pelin Agocuk ${ }^{1}$, Gökçe Keçeci ${ }^{1 *}$ \\ ${ }^{1}$ Near East University, Nicosia, N. CYPRUS
}

Received 26 September 2017 - Revised 10 November 2017 - Accepted 11 November 2017

\begin{abstract}
Mass media, which is used not only to reach many people easily but also to inform, direct, influence and educate people, is the most important devices of the 21 st Century. Cinema, which is used to educate people, as well as to entertain, influence and direct them, is accepted and used as the most important cultural conveyor of the 21st century. Cinema has the feature of reflecting the social, political and cultural changes and of contributing to reconstruction of reality. As a result of the political processes and crises in countries, the incompatibility of the social structure has brought the issue of distrust of the people against politics and politicians. This study focuses on how cinema may play role on educational patters of individuals and can even affect politicians to protect their legitimacy. This effect is searched by discourse analysis to find whether politician's education level is significant on the public within the perspective of films. The study analyses the film "Hasip and Nasip" as the case study which gave the most important and distinctive examples of 'politician representation' in the period between two coups.
\end{abstract}

Keywords: cinema, politics, politician, education, politician discourses

\section{INTRODUCTION}

Cinema, as an art form, has a power to build mental construction like "political action". Since the birth of the cinema, it has been realized that the cinema has the power to affect and direct the society, it has often been used as a propaganda tool by the parties in power in a lot of countries.

Cinema, which is seen as a fight arena, besides affecting and directing society, it is a tool that affects the cultural interaction between countries. Cinema, which is used as an arena where the existing social and political conditions, and the struggle between representation styles are reproduced, can also be defined as an area where the political discourse of the time is transferred. According to Kapani (2011) policy is an activity, which is closely related to people's lives and affects them. People, need a leader to represent and lead them because they believe these leaders will provide access to better conditions in their lives. Cinema can be considered as an effective toy $\backslash$ tool for the leaders.

According to Ryan and Kellner $(1997,15)$ cinema is an indispensable mean of production regarding ideological terms; because both have something in common that they are closely related: Representation, "film does not show anything out there," it offers by passing it through the filter of representation and converting.

Cinema as a political tool, attempts to represent the meaning and social, historical and political in daily life in which it exists. It reflects the impact of the period under the influence of cinematic ideology, social conditions and historical transformation. Cinema, which is political, means that political themes or events and phenomena will be discussed in political terms.

Political film today, means a film, which puts itself instead of someone else; shows the distance among words, sounds, images, movements and emotions by transformation style. (Rancier, 2010). Thus, the cinema has several political discourses and a political sense, even over the life of a person, can be produced.

Films prepare the ground for social reality to be built on in any way, and are part of the cultural representation system that sustains the social institutions in terms of the sense of the world (Ryan and Kellner, 1997). Even films, which are not in the political films category, made reference to the period of political and social conditions. 


\section{Contribution of this paper to the literature}

- Cinema has the feature of reflecting the social, political and cultural changes and of contributing to reconstruction of reality.

- The use of films as a teaching resource is suitable for interdisciplinary education because films represent creative forecasts helping the public realize what could occur in the future.

- Study focused on how politicians' educational levels can direct voters through cinema and policy contexts.

Mike Wayne, in his "The Political Film" book defined the concept of political film, while assessing the third film practicality in a wider context. According to Wayne $(2011,9)$ all films are political, but every film is not at the same political level. Therefore, the film analysed in this study, is not in the political films category, but representative forms that are created in the film show how everyday life is intertwined with politics.

According Dorsay (2003), politics is usually a struggle to change society and the world; cinema is an art that contributes to this change. There is an articulation and joint status between cinema and politics. Therefore, cinema contributes to social and political change, as well as offers a variety of forms of representation to maintain the current system. Films created through representation, on the one hand reflects its own period, on the other hand, they build a reality to protect the current system.

In this study, the reflection of the perception of politics, legitimacy and politician in Turkey by using 'Hasip and Nasip' made in 1976, which corresponds with the time between 1960 revolution and 1980 revolution, will be explained. The aim of the study is to determine how politics takes place in everyday life, to find out what kind of effects the level of education of the politician have on people and what kind of effects the political instabilities have on political life through films. It is also aimed to determine the effect of the level of education of politicians on the political process and the ability to become conscious voters.

\section{Cinema as an Educational Tool}

The use of films as a teaching resource is suitable for interdisciplinary education because films represent creative forecasts and predictions on future human society, helping the public realize what could occur in the future. By utilizing films in instruction, students can be trained to understand the three key functions of IoT and acquire the ability to develop creative applications of IoT. (Hwang et al., 2017). Icart et al. (2012) intends that the film constitutes an opportunity to develop the argumentative capacity of participants in a teaching session. A film containing a human story is an appropriate medium for the interdisciplinary approach indicated above. Films enable people to view life critically and can help people acquire newly required virtues. (Hwang et al., 2017)

Watching and discussing films in the classroom in the way that Giroux's film pedagogy suggests, involves activating critical judgement and the personal voice of the subject. Giroux (2004) wanted students to become democratic, political and self-critical, reading films and treating moving images like cultural texts with (political) representations of, for example, racism, gender or education. Film pedagogy is thus a confrontation of the personal beliefs inside the student with what is represented on the screen.

For Austin (2012) exploring theory through film can build theory competency in ways that not only directly represent concepts of theory on screen, but that also create a space for students to come to and draw out other forms of engagement with political theories.

Relationship between education, cinema and politics is rather a complex topic. Education plays an important role as a means of transferring cultural, material and moral values of a nation according to the conditions of the times from generation to generation. The existence of a nation, sustaining its relations with the world and its cultural values, and educating conscious individuals depends on education and education policies. Therefore, education is an important concept that maintains the functionality of each area and also provides intercultural interaction. As an important institution that forms the basis of social structure, education interacts with other institutions and provides social integration. Kahl Jr. (2013) introduces potential of teachers to question the regarding the communicative role of cinema`s power in the classroom. It is possible to educate individuals in accordance with the political, economic, socio-economic and socio-cultural conditions, but only if the educational institutions continue their interaction with other institutions properly. Politics related to education is based on the explanation of the effects of the level of education of politicians on society and social institutions in this study. In this case, when politics are discussed, conscious and effective selection and the act of being elected is in one-to-one relation with education.

The fact that voters are educated means that they consciously choose the person who governs them. The fact that the election is conscious also means that the administration and your sovereignty are in the hands of the right, educated and conscious people. As Plato's state-run title says, the elections to be made by the unconscious masses will cause sovereignty to fall into the hands of the ignorant, and the notion of democracy will be shaped by the 
chosen ignorant. A democratic form of government is only possible if the people are not elected to be the person to govern, but are educated and conscious voters.

Education has also caused a complexity as a system that affects every area from family institution to social institutions. In the period between the two coups which coincided with a process in which the ignorance of the elected people and the electorate was controversial, politics led to the emergence of ignorant politicians who had been making public promises. At this point, both the electoral consciousness and the choice of the informed and educated people who embrace democratic governance significantly influence the future of a country.

Cinema Films are useful pedagogical tools for analysis because they increase the relevancy of the concepts that are being discussed (Green, 2004) Additionally, movies can assist students in developing analytical skills (Champoux, 1999)

This study examines the effects of cinema as a means of intercultural interaction, influencing social education, awareness of the masses, and reflecting the circumstances of the era it deals with, and the issue of educated and conscious of the elector and the selected person through the 1976 film Hasip and Nasip. The relationship between politics and education is explained by focusing on what 'the level of education of politicians' should be and how ' conscious voters' should be in terms it is an obvious example on the subject.

\section{METHOD}

The focus of this study Hasip and Nasip (1976) film was chosen because it has an importance regarding 'criticizing politicians and the government through humour', 'political 1 authority egitimacy', 'political discourses' and 'the effects of politicians' education level on political process.

Discourse, explains how ideologies, our everyday topics and conversations are affected, how we understand the ideological discourse and how discourse takes place in the reproduction of ideology in society (Van Dijk, 2011). Discourse analysis method will be used to reveal how 'the political discourses', 'politician character' and 'politicians' education' fictionalized and to determine how the discourses used in the film which takes a role in the reconstruction of reality. It will also be explored through cinema to see what effect cinema has on voters' contribution to the political process and on political participation.

\section{Case Analysis of the film Hasip and Nasip}

Director: Atif Yilmaz / Screenplay: Umur Bugay / Producer: Memduh Un / Cinematography: Erdogan Engin / Cast: Zeki Alasya, Metin Akpinar, Sevket Altug / Genre: Comedy, Political.

\section{HISTORICAL FRAMEWORK}

Turkey's political situation began to be criticized due to the end of the idealization of the west in 1970s and the colonial history, imperialist expansion and cultural hegemony over Turkey (Karpat, 2011). Upon losing the power of the Western image, although Turkey was economically dependent on foreign power, started to search for ally.

For this purpose, Turkey began to approach to the African nations with the socialist block and the Muslim Arabs in the Middle East that had long been ignored (Karpat, 2011, 251). Due to the deterioration of relations with the West, Turkey had to cooperation with the Middle East and the Soviet Union. This situation forced Turkey to the past also affected the ideological developments and led to the rise of Islamism and nationalism. The extreme left ideologies and fundamentalist ideology questioned Turkey's Western orientation.

In Europe, the destruction and chaos due to World War II led to the Soviet Union rise. Europe lost its strength because of the Soviet spread, so America decided to strengthen Europe materially and spiritually. Secretary of State George Marshall, prepared a plan to improve European countries named 'Marshall Plan ' on 5 June 1947 to plan the economic development of the European states, while America provided economic and political cooperation with Europe, in order to destroy communism and the biggest threat to US. Turkey's exclusion from the Marshall Plan created a huge disappointment and Turkey's representatives applied directly to the US government and emphasised the relationship between the military and political stability, and economic situation so that they had to be included in the plan. Turkey's report asking for help from the United States in the framework of the Marshall Plan was rejected on the grounds that the plan was to ensure the development of European countries, which were damaged by the war so Turkey was not included. Moreover, American experts, on the grounds that Turkey's trade balance was in better condition than the other fifteen European countries, in the framework of the Marshall Plan, Turkey was kept responsible for exporting raw materials to European countries. Necessities like tools, transport truck, oil products, electrical supplies and tractors to be used in agriculture and mining areas were given as aid.

In the film, the problems between Hasip and Nasip (1976) who are the sons of two enemies for years that were inherited from father to son in a village were told. In the film, everything from politics to everyday life is a kind of 
Table 1. Characteristics of the politicians who were represented in the film

\begin{tabular}{llccc}
\hline $\begin{array}{l}\text { Identities of the } \\
\text { Politicians in the film }\end{array}$ & Important items & $\begin{array}{c}\text { Education Level of } \\
\text { the politicians }\end{array}$ & $\begin{array}{c}\text { Gender of the } \\
\text { Politicians }\end{array}$ & $\begin{array}{c}\text { Real occupation of } \\
\text { the Politicians }\end{array}$ \\
\hline $\begin{array}{l}\text { Hasip: } \\
\text { Religious }\end{array}$ & $\begin{array}{l}\text { Trying to get the power by using religion } \\
\text { Make Promises }\end{array}$ & College - Dropped & Male & Shopkeeper \\
\hline $\begin{array}{l}\text { Nasip: } \\
\text { Conservative }\end{array}$ & $\begin{array}{l}\text { Conservative and not open minded } \\
\text { Making promises }\end{array}$ & College -Dropped & Male & Shopkeeper \\
\hline $\begin{array}{l}\text { Vecdi: } \\
\text { Social Democrat }\end{array}$ & $\begin{array}{l}\text { Social Democrat } \\
\text { Honest } \\
\text { Do not make promises }\end{array}$ & Undergraduate & Male & Lawyer \\
\hline
\end{tabular}

competition. Passing from father to son as a family tradition, Halis and Mulis competing about everything, became the mayor annually with the consent of the villagers who got tired of their competition, which never had an end. Their mayor turns annually continued until the next mayoral election when their opponent who was educated, knowledgeable and social democrat became a candidate for mayor. These characters that compete about every issue, went to the hajj pilgrimage to fulfil their pre-election expenses and they threw stones to the devil, however, they threw stones to each other accidentally and they both died. The film's protagonists Hasip and Nasip returned to the village after their army duty and became politician to fill the position of their fathers. The both characters put their candidacy for mayor and their competition continued from especially politics to daily life. In the film, the dimension of the competition changed and according to the agreement between them they thought whoever won the municipal elections, he would marry the governor's daughter who is actually lover of the governor. But what they cannot account for is that Vecdi, who is a rival to them, is an educated and conscious politician and is a reliable person in the public.

\section{END OF THE PROMISE / HONEST POLITICIANS WINS}

The politicians' rivalry with each other was told in an exaggerated way through humour in the film, reference was made to the period's politics and politicians. In the film, Hasip character represented deputy prime minister, while Nasip represented the main oppositionary leader, the two politicians of that period. It was also criticized through humour that the struggle between the two political ideologies without much difference continued in order to be in power and to get voted, and it was also emphasized in the film that politicians were people that deceive the public with empty promises. Unlike these two characters, the political understanding of the period was criticized through the Vecdi character, who was educated, knowledgeable with no empty promises.

At the wrestling scene in the film at the background, there is a flag, which looks like, both Turkish and American. During that period, the United States made aid called Marshall Aid for strengthening the economy and politics, and public saw the USA as the saver and freedom in the film. The intensity of American sympathies was reflected in a significant way in this scene. Nasip, who was beaten at the wrestling, is a character that supports American and, Hasip character refers to a representation against the United States.

$$
\begin{aligned}
& \text { Nasip: Let it... I can give ten Liras ... can give } 20 \text { Liras. } \\
& \text { Hasip: No! If I win, my father will get me a shotgun. }
\end{aligned}
$$

The discourse used in the scene, Hasip character symbolizing an anti-American character actually criticized American sympathy and received financial assistance by refusing the money offered.

Hasip character represented the Deputy Prime Minister who has an ideology, which was Islamist and fundamentalist at that time. In this context, the character refuses America to have a word in the economy and political relations between West and Turkey.

The discourse created in the film, represents the politicians and the political situation of the period. In the 70s, Deputy Prime Minister who was one of the politicians defending the Cyprus Operation with Prime Minister, was called as' soldier'.

The character Hasip, who uses the name of God at his every step, is called, as 'soldier' in the film so he is a clear representation of Deputy Prime Minister. The character Nasip represented the main opposition party leader`s discourse and promises.

According to Baudrillard (1981), citizens in a modern democratic country that is restricted by term election campaign, political speeches made via the parties, working full-time since 1970s and official political consultants whose numbers expressed in hundreds and the "structured" speeches which come through after filtering of experts has been transformed into a political talk show area $(1991,17)$ 
In one scene of the film; when Nasip and Hasip were making political rallies to the public in the town square, Vecdi character and his representatives were watching their parade from the coffee shop.

Tea Servant: Mr Vecdi! Yours are making body show in the town.

Vecdi: Let them do. They can show their empty bodies; it does not matter because their heads are empty....

The discourse created in this scene shows clearly that politics and political speech is a kind of performing art. In the film, Vecdi, representing an educated and reliable politician who never did a show and never made empty promises, won the election, is a message to the audience. It was also emphasized and showed how 'political discourse' and how 'a real politician' should be when the people, who do not believe the election promises and political demonstrations, make the right choice.

In another scene in the film, Nasip character made a bridge over a dry creek in the town before the election to win votes.

While the opening of the bridge, in his speech;

\section{Nasip: I am opening this great bridge, which will connect the four continents. I will not ask any pass fee.}

Hasip before the opening of the bridge plans an operation to ensure the destruction of the bridge. On the opening day of the bridge, it collapsed while Nasip character and its supporters were passing by.

On the other hand, Hasip made a fountain in the square of the town. On the opening day in his speech

Hasip: we are here to open the great fountain of the Middle East and Balkans.

He says the above written sentence and invites the Mayor to open the fountain. Nasip put dynamite before the opening of the fountain and wanted to prevent Mayor to open the fountain. The fountain opening was done and the dynamite did not explode.

According to Rancière (2007: 22), the idea of the end of politics; instead of promises made by politicians before each election and promises which were not kept, the idea which accepts politics as improving the world's energy, using the ship in a rational way, seeing the politics preventing civil war was accepted.

This scene emphasizes how empty election promises are and the things done for the people are nothing more than a show, and the characters represented as 'politician' makes empty promises to get the power and for the sake of maintaining the sovereignty. Today, election promises of the "70s came to this day with little difference and so it reveals that there is nothing changed.

In the rally scene in the film, Necmettin Erbakan's discourse, which represents an ideology of Islamist and fundamentals of the period, has been criticized:

Hasip- There is no moral left in the country! Women and girls are in the streets.

What are women doing in politics dear? A woman is a mockingbird in a cage. If you vote for me, I will forbid uncovered women and miniskirts.

I will make our daughters wear long pants on our public holidays.

At the end of the meeting, the women are chasing Hasip with sticks. While he is escaping from women, he points out the posters of a naked woman on the wall and says, "You would be like this." While women are chasing him saying 'bigot', he asks for help from Nasip when they encounter.

\section{Nasip; "These are Vecdi's party's women part" says and laughs sarcastically.}

In this scene, the ideology, which is supported by Hasip and Nasip was criticized and shows that there is no difference between the two views from each other. The common defence which is reflected in the films is the view which gives no chance to women equality, freedom and do not give any rights to women so the social democratic Vecdi is glorified. The discourse created here that the public do not want the politicians who want to get into power and fight only for this and who try to make use of them.

Corresponding to the day before the election in the film on "The town's Independence Day" celebration, one of the men came next to the Hasip sitting at the table and whispered in his ear; 
-Nasip's men are giving out 25 quid per man in Sultan Hill neighbourhood.

Hasip says 'You give thirty!'

One of his own men came next to the table where Nasip was sitting and says;

-'I arranged 80 people from Iribaba neighbourhood. They will vote in four polls.

Nasip says 'Good!'

This contains the mutual interest relationship between the interests of politicians and the interests of different sections forming community "give, receive and refund the money more as a return to what received". This method is called 'Potlatch theory", it is the relation between the giving hand and the taking hand, and the rule of the game is not to become a taking hand because taking hand has to obey (Saliji, 2008, 354).

Looking at the overall politics, the people who deal with politics, make promises, and they obey in return, but when it turns into this mutual exchange relationship, people want form politicians and politician fulfils this desire to win the election.

The discourse in the film, the promises of politicians and politics in the 70s and today are reflected. Rancierre's 'the end of the promise' is given at the end of the film. Now, people do not want politicians who exaggerate promises and bribe for the sake of getting into power. The moral lesson of the film was when the honest character Vecdi who never made any promises won the election, and the politicians and political actions of that period was criticized harshly through humour.

Hasip's rally speech:

Neither French concord aircraft, nor Americans Phantom aircraft is needed. For God's sake, we'll make our own plane. We will set up factories here. Not only plane! Thousands of tanks, hundred thousand motorbikes....

At this scene, the politicians' promises were reflected in an exaggerated way. People show exuberant welcome to these promises even they know that they are not real, however, Vecdi who represents an honest and educated politician wins the election and it shows that those promises were meaningless. This scene gives the message that politics is not a performing art. In particular, the film has given the message that politics is not a show, but that knowledgeable and educated politicians are more successful in government so people can make the right choices as long as the right people are in politics.

\section{DISCUSSION \& CONCLUSION}

This study included the historical and social context of the representation of politicians in Turkish films through the 1976 Hasip and Nasip film. It focused on how politicians' educational levels can direct voters through cinema and policy contexts.

It is found that the policy making actions and politician representations created in the film are tracing the political understanding in Turkey at that time. The film, through the representation of politicians, has been found to reflect the characteristics of the period as well as to criticize the existing political order and power relations.

It can be argued that people are looking for honest politicians who do not give empty promises to the public. The ones with exaggerated promises are no longer supported by people. In the film, the two basic characters who give empty promises, ignorant and uneducated has not struggled to win the elections while Vecdi who is educated, conscious and social democratic has won the elections. Thus, the film has been given the message that a conscious and educated politician can also constitute a mass of conscious voters that may make the right choice.

Similar techniques were used in Czech Republic at similar times in cinemas. As Cesalkova (2012) notes, together with the idea of educating film audiences in mainstream cinemas marginalized, hidden outside the official structures, in non-theatrical exhibition venues, a very specific conception of closed screenings set in didactic circumstances evolved.

In Iran similarly, the development of cinema and its propagation across the country in the pre-revolutionary era, elicited various reactions from the religious establishment, intelligentsia, political activists, cinema enthusiasts, and the general public; especially after 1941. (Rekabtalei, 2015)

The politicians represented in the film industry were generally seen as ignorant and illiterate towards people who act in their own favour and emphasized the political process, crises and the victimization of the people in Turkey. 
The ideology created in the film advocates the idea of bringing an innovation to the 'political understanding' of the period, and also that politicians should act in the favour of people not themselves and they should be educated and conscious.

Selection campaigns and rally footage are frequently seen in the 1976 film "Hasip Nasip" directed by Atıf Yllmaz. The Film's production date came a year before the midterm elections in Turkey. The fact that the advertising sector in Turkey is making great progress has also been the subject of political advertising's widespread repercussions. In this context, it is the contest of the two mayor candidates, especially in the film. Besides being a lawyer on the other candidate, it is also remarkable that he is displayed consciously and honestly.

The film is a kind of comedy film in which a lot of political games are played and projected. The fact that politicians are usually shown as fraudulent in Turkish films is emphasized only on the ignorance of candidates who are not emphasized much in this film. One of the candidates is carrying a tassel in a hand with a grey long coat fur hat and almond moustache. The other candidate walks in a suit. The serious criticism of the term politicians finally won the honorary presidential candidate.

The film analysis that was examined in the research showed that although the depoliticized people were consciously irrelevant to politics, they were able to question politics and politicians through cinema. Hasip and Nasip (1976), which is a representative of politicians in cinema, is not only about the politics of the era that they belong to, but also about the nature of politics today. Comments on the powerful effect of cinema are remarkable: Duhamel's phrase the thoughts in our heads have been removed by moving images is not necessarily problematic. (Decoster and Vansieleghem, 2014). Deleuze (1986) invites us to allow cinema's potential to work on us, in this way realizing thinking, paradoxically, through the act of not-thinking.

\section{REFERENCES}

Austin, E. K. (2012). Cinema and Public Administration Theory in the Classroom. Administrative Theory $\mathcal{E}$ Praxis, 34(1), 114-119.

Baudrillard, J. (1981). A sociedade de consumo. Lisboa: Edições, 70.

Česálková, L. (2012). Cinema outside cinema: Czech educational cinema of the 1930s under the control of pedagogues, scientists and humanitarian groups. Studies in Eastern European Cinema, 3(2), 175-191.

Champoux, J. E. (1999). Film as a teaching resource. Journal of Management Inquiry, 21, 206-217. doi:10.1177/105649269982016

Decoster, P. J., \& Vansieleghem, N. (2014). Cinema education as an exercise in 'Thinking Through NotThinking'. Educational Philosophy and Theory, 46(7), 792-804, doi:10.1080/00131857.2013.795853

Deleuze, G. (1986). Cinema 1: The movement-image (H. Tomlinson \& B. Habberjam, Trans.). London: Athlone Press. (Original work published 1983).

Dorsay, A. (2013). Quo Vadis Istanbul. Istanbul: Remzi.

Giroux, H. (2004). Pedagogy, film, and the responsibility of intellectuals: A Response. Cinema Journal, 43, 119-126.

Green, R. J. (2004). Teaching psychology through film, video. In Lessons learned: Practical advice for the teaching of

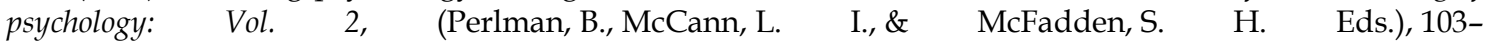
110. Washington, DC: American Psychological Society.

Hwang, Y. M., Kim, K. S., \& Im, T. (2017). Film scenes in interdisciplinary education: teaching the Internet of Things. Educational Media International, 54(2), 83-98.

Icart, I. M., Martínez, B. M., \& Icart, I. M. (2012). The film as a teaching resource (Part II). How to prepare a session. Revista de enfermeria (Barcelona, Spain), 35(12), 30-2.

Kahl Jr, D. H. (2013). Viewing critical communication pedagogy through a cinematic lens. Communication Teacher, 27(2), 99-103.

Kapani, M., (2007) Introduction to Political Science, 19th Ed. Ankara, Bilgi Publishing House.

Karpat, K. H. (2011). Turkish Political History, The Evolution of Political Systems, 2nd Ed. (Trans. Ceren Elitez). İstanbul: Timaş Publishing.

Kışlalı, A. T. (2014). Political Science, 16th Ed. Ankara: İmge Publishing House.

Ranciére, J. (2007) Political Coast (Trans. Aziz Ufuk Kılıç). İstanbul: Metis Publishing.

Rekabtalaei, G. (2015). Cinematic Revolution: Cosmopolitan Alter-cinema of Pre-revolutionary Iran. Iranian Studies, 48(4), 567-589.

Ryan, M., \& Douglas, K. (2010). Political camera, Trans. Elif Özsayar, İstanbul: Ayrıntı Publishing. 
Saliji, S, (2008). The Place Where Cherry Taste Mixed with the Wind: "Vantel" (Potlatch Culture and An Essay on Cinema), Cinema, Ideology, Politics: "Fascinating Fascism and Other Writings". Ankara: Öncü Publishing House. Van Dijk, T. A. (Ed.). (2011). Discourse studies: A multidisciplinary introduction. Thousand Oaks, California, U.S.: Sage. Wayne, M. (2011). Political Film: Third Cinema Dialectics (Trans. Ertan Y1lmaz). İstanbul: Yordam Book.

\section{http://www.ejmste.com}

